\title{
Enhancement of poorly edible phytoplankton by allochthonous dissolved organic material: a modelling study
}

\author{
Willem Stolte $^{1, *}$, Torsten Lindström $^{2}$, Edna Granéli ${ }^{1}$ \\ ${ }^{1}$ Marine Science Division, and ${ }^{2}$ Division of Mathematics, School of Pure and Applied Natural Sciences, \\ University of Kalmar, 39182 Kalmar, Sweden
}

\begin{abstract}
The effect of different input rates of dissolved inorganic (DIN) and organic (DON) nitrogen on a microbial food web was studied with the help of a mathematical model. Three species of phytoplankton were modelled, with trade-off characteristics for maximum per capita growth rate, half-saturation constant and edibility. Bacteria used only DON, while 2 different types of microzooplankton grazed on the bacteria and phytoplankton species. DON stimulated bacterial growth and phytoplankton growth via mineralization of nitrogen by the bacteria. At moderate and high DIN and/or DON input rates, the poorly edible phytoplankton species became the dominant phototroph. However, the biomass of the poorly edible phytoplankton species, and the proportional contribution of this species to total phytoplankton biomass, was more correlated with changes in DON input rates than DIN input rates. Furthermore, the abundance of the poorly edible phytoplankton was most sensitive to changes in the maximum grazing rate of the ciliate. The enhanced mass flow through the heterotrophic members of the food web enhanced the grazing pressure on all members of the microbial community, including phytoplankton, and caused the shift towards a grazing-resistant phytoplankton community. We formulated the testable hypothesis that input of allochthonous dissolved organic nutrients may contribute to blooms of poorly edible algae through food web interactions.
\end{abstract}

KEY WORDS: Allochthonous DOC • Microbial food web · Modelling • Selective grazing • Phytoplankton · Harmful algal blooms

\section{INTRODUCTION}

The occurrence and persistence of harmful or nuisance phytoplankton blooms are, among other factors, the result of their relative resistance to grazing. Modelling studies have provided a better theoretical framework of the mechanisms (e.g. Thingstad \& Sakshaug 1990, Riegman \& Kuipers 1994). In general, at low input rates of a growth rate-controlling nutrient supply to a pelagic food web, the phytoplankton with the highest affinity for this nutrient will become dominant. As a result of their superior surface to biomass ratio, these phytoplankton are usually picocyanobacteria or microflagellates (Stolte \& Riegman 1995). Such small phytoplankton are grazed by microzooplankton grazers that have per capita growth rates similar to their own, and are therefore under strong numerical control. At higher input rate of the controlling nutrient, the extra resources will therefore not result in a higher biomass of the existing phytoplankton population, but will instead be used by phytoplankton species, e.g. larger diatoms, that are not under the instant numerical control of their grazers. When a high resource input rate is sustained for longer periods, a niche is created for slowly growing, but poorly edible phytoplankton species (Andersen 1997). Resistance against grazing could be accomplished through sufficient size, chemical and mechanical defence, toxicity, and a combination of those factors (Turner \& Tester 1997, Turner 2006). With ample available nutrients, grazer-resistant phytoplankton species might form harmful blooms, causing different negative effects (Zingone \& Enevoldsen 2000). 
Riverine input to coastal marine waters is not only in the form of inorganic nutrients, but also as nutrients bound to dissolved organic material (DOM) (Stepanauskas et al. 2000). Direct use of organic material by phytoplankton, including toxic species, is known to occur (Antia et al. 1991, Berg et al. 1997, Legrand \& Carlsson 1998). However, in natural systems, DOM is more likely to end up in the microbial food web via bacteria because of their higher affinity for most solutes. Enhanced production of heterotrophic bacteria by riverine DOM will increase the production and biomass of microzooplankton grazers that are also capable of grazing on phytoplankton. This increase in grazers could then enhance the selection towards poorly edible phytoplankton species. Moreover, although the degradability of DOM may vary during a season, the imported DOM usually shows less seasonal variation than DOM provided via primary production (Stepanauskas et al. 2000). In environments with a high load of DOM, spring phytoplankton blooms may have to develop in subsidized microbial communities sustained by the externally supplied DOM, where zooplankton grazers are already present. Therefore, in pelagic systems with a high load of dissolved organic nutrients, phytoplankton succession might be subjected to more top-down control, and selection towards non-edible species might thus be stronger than in comparable systems in which only inorganic nutrients are available.

With the use of a simple model, we explored possible effects of imported organic material, additional to the effect of different loads of inorganic nutrients, on a simulated microbial food web. We hypothesised that input of organic material might lead to increased abundance of poorly edible phytoplankton species, owing to (1) increased availability of nutrients and (2) increased flow of imported organic matter through the heterotrophic part of the food web, increasing the grazer population and thereby the grazing pressure on all phytoplankton. Sensitivity analysis was used to explore the relative importance of these 2 effects.

\section{MODEL DESCRIPTION}

The model describes a microbial food web, and contains 8 state variables representing dissolved inorganic nitrogen (DIN), dissolved organic nitrogen (DON), 3 species of phytoplankton $(P 1, P 2, P 3), 1$ type of bacteria $(B)$ and 2 types of grazers - a heterotrophic nanoflagellate (HNAN) and a ciliate (CIL) (Fig. 1, Table 1). The main assumptions and characteristics of the model are given below.

Nitrogen availability control: We assume that, as in most marine systems, primary production is limited by nitrogen availability. In that case, it is sufficient to describe only the nitrogen budgets for all state variables. This may not always be appropriate. However, the alternative (variable elemental ratios for all groups of organisms) would make the model far more complex, and the outcome more difficult to relate to the parameter values.

Phytoplankton characteristics: The different phytoplankton species can only take up DIN. The growth affinity for DIN is highest for the competitive species $P 1$. The maximum per capita growth rate is highest for the opportunistic species $P 2$. The poorly edible species $P 3$ is the poorest competitor for nutrients and has the lowest maximum per capita growth rate (Fig. 2).

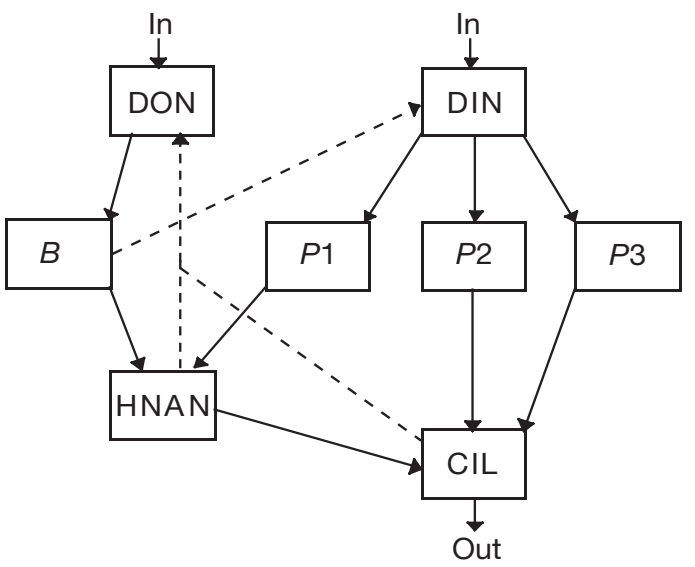

Fig. 1. Structure of the model. Arrows indicate transport route of nitrogen, dashed lines indicate recycling

Table 1. State variables used in the model and summary of main features

\begin{tabular}{lll}
\hline Variable & Description & Main features \\
\hline DIN & Dissolved inorganic nitrogen & Continuous input, taken up by $P 1, P 2$ and $P$ 3, excreted by $B$ \\
DON & Dissolved organic nitrogen & Continuous input, taken up by $B$, excreted by HNAN and CIL \\
$P 1$ & Phytoplankton species 1 & Good competitor for DIN, intermediate $\mu_{\text {max }}$, consumed by HNAN \\
$P 2$ & Phytoplankton species 2 & Intermediate competitor, high $\mu_{\text {max }}$ consumed by CIL \\
$P 3$ & Phytoplankton species 3 & Poor competitor, low $\mu_{\text {max }}$ least preferred by grazers, consumed by CIL \\
$B$ & Heterotrophic bacteria & Consume DON, excrete excess N as DIN, consumed by HNAN \\
HNAN & Heterotrophic nanoflagellates & Consume $B$ and $P 1$, consumed by CIL, excrete excess N as DON \\
CIL & Ciliates & Consume $P 2, P 3$, and HNAN, excrete excess N as DON, density-dependent removal \\
& &
\end{tabular}


Forced nitrogen input dominance: In the model, no excretion of DON by phytoplankton is considered. We assume that when $\mathrm{N}$ is limiting phytoplankton growth, algal DON excretion will not significantly contribute to the DON pool compared with the forced inputs of allochthonous organic material in the model. DIN and DON are added to the system with a constant rate.

Monod phytoplankton growth: According to Monod's kinetics, phytoplankton per capita growth rate is directly (and only) dependent on extracellular DIN concentrations. In periods of rapidly changing nutrient concentrations, this approximation is incorrect, owing to physiological adaptation of phytoplankton to nutrient limitation (e.g. Rhee 1973). However, in situations close to steady-state conditions, this approximation will be as good as a more complicated internal nutrient stores model (Burmaster 1979).

DON control of bacteria: Bacteria per capita growth rate is only dependent on DON. The efficiency of $\mathrm{N}$ assimilation is lower than $100 \%$, meaning that some of the nitrogen will be excreted as DIN, after which it is available to the phytoplankton. In natural circumstances, the percentage of DON that will be excreted as DIN will depend on the $\mathrm{C} / \mathrm{N}$ ratio of the DON, the $\mathrm{C} / \mathrm{N}$ ratio of bacterial biomass, and the respiration rate. In our model, the efficiency is treated as a constant. Because only $\mathrm{N}$ compounds are modelled, bacteria can only grow when DON is available. In natural systems, the availability of carbon facilitates bacterial DIN uptake by bacteria and therefore competition with phytoplankton. This process is not considered here.

Grazers ingest heterotrophic and autotrophic prey: In our model, CIL feeds on HNAN, $P 2$ and P3. HNAN also eats heterotrophic and autotrophic prey, and consumes $B$ and $P 1$. An underlying assumption is thus that heterotrophic phagotrophs do not select strongly between heterotrophic and autotrophic prey. Experimental evidence is scarce, but has demonstrated this for at least some marine protists (Christaki et al. 1998).

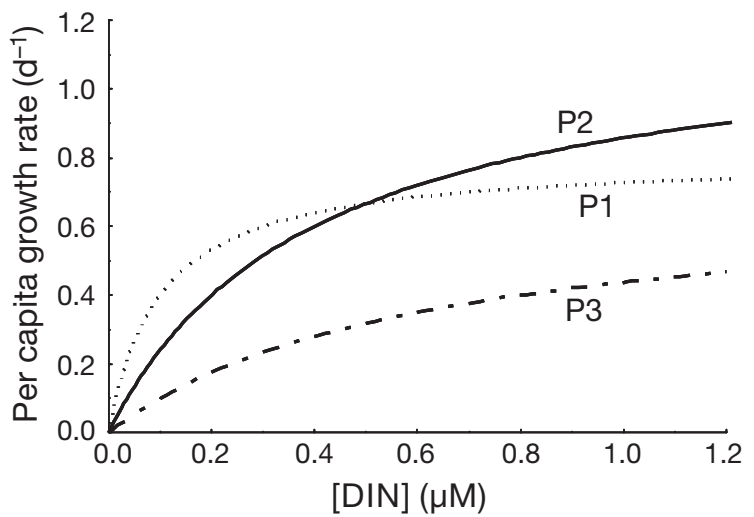

Fig. 2. Per capita growth rates of 3 phytoplankton species used in the model, as a function of external DIN concentration
Recycling of excess $\mathbf{N}$ by grazers: The nitrogen assimilation efficiencies of HNAN and CIL are less than $100 \%$, implying nitrogen excess during ingestion and digestion of the prey. The unassimilated nitrogen is released as DON and may become available for phytoplankton after uptake by bacteria.

Density dependent CIL removal: The CIL biomass is removed from the system at a rate proportional to the square of CIL concentration, analogous to the loss rate in the logistic model, reflecting grazing by higher trophic levels. It is assumed that none of the nitrogen from the removed ciliates is returned into the microbial food web.

Formal description of the model. Phytoplankton growth was modelled according to Monod kinetics (Eqs. 1 to 3, see Tables $1 \& 2$ for state variables and parameters, respectively):

$$
\begin{aligned}
& \frac{\mathrm{d}[P 1]}{\mathrm{d} t}=[P 1] \frac{\mu_{\text {max }, P 1}[\mathrm{DIN}]}{k_{\mathrm{DIN}, P 1}+[\mathrm{DIN}]}-[\mathrm{HNAN}] \frac{g_{\mathrm{max}, \mathrm{HNAN}} \frac{[P 1]}{k_{P 1, \mathrm{HNAN}}}}{1+\frac{[P 1]}{k_{P 1, \mathrm{HNAN}}}+\frac{[B]}{k_{B, \mathrm{HNAN}}}}(1) \\
& \frac{\mathrm{d}[P 2]}{\mathrm{d} t}=[P 2] \frac{\mu_{\mathrm{max}_{,} P 2}[\mathrm{DIN}]}{k_{\mathrm{DIN}, P 2}+[\mathrm{DIN}]} \\
& -[\mathrm{CIL}] \frac{g_{\max , \mathrm{CIL}} \frac{[P 2]}{k_{P 2, \mathrm{CIL}}}}{1+\frac{[P 2]}{k_{P 2, \mathrm{CIL}}}+\frac{[P 3]}{k_{P 3, \mathrm{CIL}}}+\frac{[\mathrm{HNAN}]}{k_{\mathrm{HNAN}, \mathrm{CIL}}}} \\
& \frac{\mathrm{d}[P 3]}{\mathrm{d} t}=[P 3] \frac{\mu_{\mathrm{max}, P 3}[\mathrm{DIN}]}{k_{\mathrm{DIN}, P 3}+[\mathrm{DIN}]} \\
& -[\mathrm{CIL}] \frac{g_{\text {max }, \mathrm{CIL}} \frac{[P 3]}{k_{P 3, \mathrm{CIL}}}}{1+\frac{[P 2]}{k_{P 2, \mathrm{CIL}}}+\frac{[P 3]}{k_{P 3, \mathrm{CIL}}}+\frac{[\mathrm{HNAN}]}{k_{\mathrm{HNAN}, \mathrm{CIL}}}}
\end{aligned}
$$

Bacterial per capita growth rate was a function of DON concentration according to Monod kinetics:

$\frac{\mathrm{d}[B]}{\mathrm{d} t}=[B] \frac{\mu_{\mathrm{max}, B}[\mathrm{DON}]}{k_{\mathrm{DON}, B}+[\mathrm{DON}]}-[\mathrm{HNAN}] \frac{g_{\mathrm{max}, \mathrm{HNAN}} \frac{[B]}{k_{B, \mathrm{HNAN}}}}{1+\frac{[P 1]}{k_{P 1, \mathrm{HNAN}}}+\frac{[B]}{k_{B, \mathrm{HNAN}}}}(4)$

The formulations for grazing preference were adopted from Fasham et al. (1999). Part of the ingested nitrogen is used for growth by the grazer, while the rest is excreted as DIN (Eqs. 5 \& 6).

$$
\begin{aligned}
& \frac{\mathrm{d}[\mathrm{HNAN}]}{\mathrm{d} t}=-[\mathrm{CIL}] \frac{g_{\text {max, } \mathrm{CIL}} \frac{[\mathrm{HNAN}]}{k_{\mathrm{HNAN}, \mathrm{CL}}}}{1+\frac{[P 2]}{k_{P 2, \mathrm{CIL}}}+\frac{[P 3]}{k_{P 3, \mathrm{CIL}}}+\frac{[\mathrm{HNAN}]}{k_{\mathrm{HNAN}, \mathrm{CIL}}}} \\
& +g_{\text {max }, \mathrm{HNAN}}[\mathrm{HNAN}]\left(\frac{e_{B, \mathrm{HNAN}} \frac{[B]}{k_{\mathrm{B}, \mathrm{HNAN}}}+e_{P 1, \mathrm{HNAN}} \frac{[P 1]}{k_{B, \mathrm{HNAN}}}}{1+\frac{[B]}{k_{B, \mathrm{HNAN}}}+\frac{[P 1]}{k_{P 1, \mathrm{HNAN}}}}\right)
\end{aligned}
$$


Table 2. Description and values of parameters (unless otherwise stated in the text)

\begin{tabular}{|c|c|c|c|}
\hline Parameter & Description & Value & Unit \\
\hline$\mu_{\max , P 1}$ & Maximum per capita growth rate of phytoplankton $P 1$ & 0.8 & $d^{-1}$ \\
\hline$\mu_{\max , P 2}$ & Same for $P 2$ & 1.2 & $\mathrm{~d}^{-1}$ \\
\hline$\mu_{\max , P 3}$ & Same for $P 3$ & 0.7 & $d^{-1}$ \\
\hline$\mu_{\max , \mathrm{B}}$ & Same for bacterial species $B$ & 1.5 & $\mathrm{~d}^{-1}$ \\
\hline$k_{\mathrm{DIN}, P 1}$ & Half-saturation constant for $P 1$ growth on DIN & 0.1 & $\mu \mathrm{mol} \mathrm{N} \mathrm{l^{-1 }}$ \\
\hline$k_{\mathrm{DIN}, P 2}$ & Same for $P 2$ & 0.4 & $\mu \mathrm{mol} \mathrm{N} \mathrm{l^{-1 }}$ \\
\hline$k_{\mathrm{DIN}, P 3}$ & Same for $P 3$ & 0.6 & $\mu \mathrm{mol} \mathrm{N} \mathrm{^{-1 }}$ \\
\hline$k_{\mathrm{DON}, B}$ & Half-saturation constant for $B$ growth on DON & 0.1 & $\mu \mathrm{mol} \mathrm{N} \mathrm{l^{-1 }}$ \\
\hline$g_{\max , \mathrm{CIL}}$ & Maximum per capita grazing rate of ciliates & 2 & $d^{-1}$ \\
\hline$k_{P 2, \mathrm{CIL}}$ & Half-saturation constant for CIL grazing on $P 2$ & 8 & $\mu \mathrm{mol} \mathrm{N} \mathrm{l^{-1 }}$ \\
\hline$k_{P 3, \mathrm{CIL}}$ & Half-saturation constant for CIL grazing on $P 3$ & 40 & $\mu \mathrm{mol} \mathrm{N} \mathrm{l^{-1 }}$ \\
\hline$K_{\mathrm{HNAN}, \mathrm{CIL}}$ & Half-saturation constant for CIL grazing on HNAN & 4 & $\mu \mathrm{mol} \mathrm{N} \mathrm{^{-1 }}$ \\
\hline$g_{\text {max,HNAN }}$ & Maximum per capita grazing rate of HNAN & 4 & $d^{-1}$ \\
\hline$k_{P 1, \mathrm{HNAN}}$ & Half-saturation constant for HNAN grazing on $P 1$ & 10 & $\mu \mathrm{mol} \mathrm{N} \mathrm{l^{-1 }}$ \\
\hline$k_{B, \mathrm{HNAN}}$ & Half-saturation constant for HNAN grazing on $B$ & 10 & $\mu \mathrm{mol} \mathrm{N} \mathrm{l^{-1 }}$ \\
\hline$r_{\mathrm{CIL}}$ & Removal rate constant for ciliate biomass & 0.3 & $1 \mu \mathrm{mol} \mathrm{N} \mathrm{N}^{-1} \mathrm{~d}^{-1}$ \\
\hline$e_{\mathrm{DON}, B}$ & Efficiency of DON assimilation by $B$ & 0.8 & No unit \\
\hline$e_{B, \mathrm{HNAN}}$ & Efficiency of $B$ digestion by HNAN & 0.8 & No unit \\
\hline$e_{P 1, \mathrm{HNAN}}$ & Efficiency of $P 1$ digestion by HNAN & 0.8 & No unit \\
\hline$e_{P 2, \mathrm{CIL}}$ & Efficiency of $P 2$ digestion by CIL & 0.8 & No unit \\
\hline$e_{P 3, \mathrm{CIL}}$ & Efficiency of $P 3$ digestion by CIL & 0.8 & No unit \\
\hline$e_{\mathrm{HNAN}, \mathrm{CIL}}$ & Efficiency of HNAN digestion by CIL & 0.8 & No unit \\
\hline$i_{\mathrm{DIN}}$ & Input rate of DIN & $0-20$ & 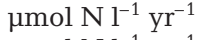 \\
\hline$i_{\mathrm{DON}}$ & Input rate of $\mathrm{DON}$ & $0-20$ & 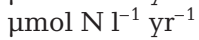 \\
\hline
\end{tabular}

$$
\begin{aligned}
& \frac{\mathrm{d}[\mathrm{CIL}]}{\mathrm{d} t}=g_{\mathrm{max}, \mathrm{CIL}}[\mathrm{CIL}] \\
& \left(\frac{e_{P 2, \mathrm{CIL}} \frac{[P 2]}{k_{P 2, \mathrm{CIL}}}+e_{P 3, \mathrm{CIL}} \frac{[P 3]}{k_{P 3, \mathrm{CIL}}}+e_{\mathrm{HNAN}, \mathrm{CIL}} \frac{[\mathrm{HNAN}]}{k_{\mathrm{HNAN}, \mathrm{CIL}}}}{1+\frac{[P 2]}{k_{P 2, \mathrm{CIL}}}+\frac{[P 3]}{k_{P 3, \mathrm{CIL}}}+\frac{[\mathrm{HNAN}]}{k_{\mathrm{HNAN}, \mathrm{CIL}}}}\right)-r_{\mathrm{CIL}}[\mathrm{CIL}]^{2}
\end{aligned}
$$

DIN and DON dynamics was calculated as a result of mass balance, and a continuous input rate of DIN (i $\left.i_{\text {DIN }}\right)$ and DON $\left(i_{\mathrm{DON}}\right)$

$$
\begin{aligned}
\frac{\mathrm{dDIN}}{\mathrm{d} t}= & -P 1 \frac{\mu_{\mathrm{max}, P 1}[\mathrm{DIN}]}{k_{\mathrm{DIN}, P 1}+[\mathrm{DIN}]}-P 2 \frac{\mu_{\mathrm{max}, P 2}[\mathrm{DIN}]}{k_{\mathrm{DIN}, P 2}+[\mathrm{DIN}]}-P 3 \frac{\mu_{\mathrm{max}, P 3}[\mathrm{DIN}]}{k_{\mathrm{DIN}, \mathrm{P} 3}+[\mathrm{DIN}]} \\
& +\frac{i_{\mathrm{DIN}}}{365}+[B]\left(1-e_{\mathrm{DON}, B}\right) \frac{\mu_{\mathrm{max}, B}[\mathrm{DON}]}{k_{\mathrm{DON}, B}+[\mathrm{DON}]}
\end{aligned}
$$

$$
\begin{aligned}
& \frac{\mathrm{dDON}}{\mathrm{d} t}=\frac{i_{\mathrm{DON}}}{365}-\frac{[B]}{e_{\mathrm{DON}, B}} \frac{\mu_{\mathrm{max}, B}[\mathrm{DON}]}{k_{\mathrm{DON}, B}+[\mathrm{DON}]} \\
& +g_{\text {max }, \mathrm{HNAN}}[\mathrm{HNAN}] \frac{\left(1-e_{B, \mathrm{HNAN}}\right) \frac{[B]}{k_{B, \mathrm{HNAN}}}+\left(1-e_{P 1, \mathrm{HNAN}}\right) \frac{[P 1]}{k_{P 1, \mathrm{HNAN}}}}{1+\frac{[P 1]}{k_{P 1, \mathrm{HNAN}}}+\frac{[B]}{k_{B, \mathrm{HNAN}}}} \\
& +g_{\text {max }, \mathrm{CIL}}[\mathrm{CIL}] \frac{\left(1-e_{P 2, \mathrm{CIL}}\right) \frac{[P 2]}{k_{P 2, \mathrm{CIL}}}+\left(1-e_{P 3, \mathrm{CIL}}\right) \frac{[P 3]}{k_{P 3, \mathrm{CIL}}}+\left(1-e_{\mathrm{HNAN}, \mathrm{CIL}}\right) \frac{[\mathrm{HNAN}]}{k_{\mathrm{HNAN}, \mathrm{CIL}}}}{1+\frac{[P 2]}{k_{P 2, \mathrm{CIL}}}+\frac{[P 3]}{k_{P 3, \mathrm{CIL}}}+\frac{[\mathrm{HNAN}]}{k_{\mathrm{HNAN}, \mathrm{CIL}}}}
\end{aligned}
$$

Parameterization. Within a given set of growth parameters of the phytoplankton species, the occurrence and persistence of this species will be dependent on its edibility. Since there is very little quantitative information in the literature on grazing preferences for certain phytoplankton species by microzooplankton, a grazing preference value for $P 3$ was chosen so that $P 3$ could occur and persist in a system with moderate nutrient input. Assuming a trade-off mechanism for grazing resistance and growth (Andersen 1997), phytoplankton species that invest in being poorly edible will be selected to spend no more energy than is needed to make the strategy worthwhile. Any more energy spent will lead to a loss in growth rate, and will not result in the persistence of this species.

Maximum growth rates and half-saturation constants for growth on inorganic nitrogen were chosen so that a clear difference appeared between the affinities $\left(\mu_{\max } / k_{\mathrm{DIN}}\right)$ of the different species for inorganic nitrogen (Fig. 2).

The growth kinetics for the bacteria were chosen rather arbitrarily. Because no competition for organic substances with phytoplankton is assumed, the actual values for $\mu_{\text {max }}$ and $k_{\text {DIN }}$ will mostly influence bacterial biomass and residual concentrations of DON but not the trends in model results. Parameter values summarized in Table 2 were used throughout this study unless stated otherwise. 
Sensitivity analysis. The sensitivity of steady-state values of the state variables to a $1 \%$ increase in all parameter values was tested at $i_{\text {DIN }}=5, i_{\text {DON }}=5 \mu \mathrm{mol} \mathrm{N}$ $\mathrm{l}^{-1} \mathrm{yr}^{-1}$ and at $i_{\mathrm{DIN}}=15, i_{\mathrm{DON}}=15 \mu \mathrm{mol} \mathrm{N}{ }^{-1} \mathrm{yr}^{-1}$, respectively. The relative change $(\alpha)$ of $X(P 3)=P 3 /(P 1+P 2$ $+P 3$ ) for any parameter value $c$ was calculated as:

$$
\alpha_{c}=\left(\frac{X(P 3)_{c+\Delta c}-X(P 3)_{c}}{X(P 3)_{c}}\right)
$$

where $\Delta c=0.01 \mathrm{C}$ for all parameters.

\section{RESULTS}

\section{Steady-state results}

Steady-state results from different DIN and DON input rates were obtained by running the model for 5000 simulated days. Usually, steady state (less then $1 \%$ variation in state variables with time) was achieved well before $1000 \mathrm{~d}$ of simulation. The steadystate results appeared to be independent of the start conditions (assuming all initial state variables $>0$ ).

In the case that no DON entered the system, $P 1$ was the dominant phytoplankton species at a low DIN input rate. The absolute biomass of $P 1$ was positively correlated with the DIN input rate (Fig. 3). Biomass of the poorly edible $P 3$ was also positively correlated with DIN input (Fig. 4), leading to an approximate $50 \%$ contribution of $P 3$ to the total phytoplankton biomass

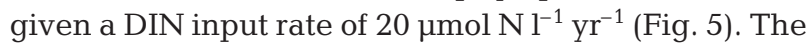
opportunistic species $P 2$ was only abundant during early phases of simulations. In time, $P 2$ was replaced by $P 1$ and $P 3$ under all tested circumstances. In fact, steady-state results were exactly the same if $P 2$ was

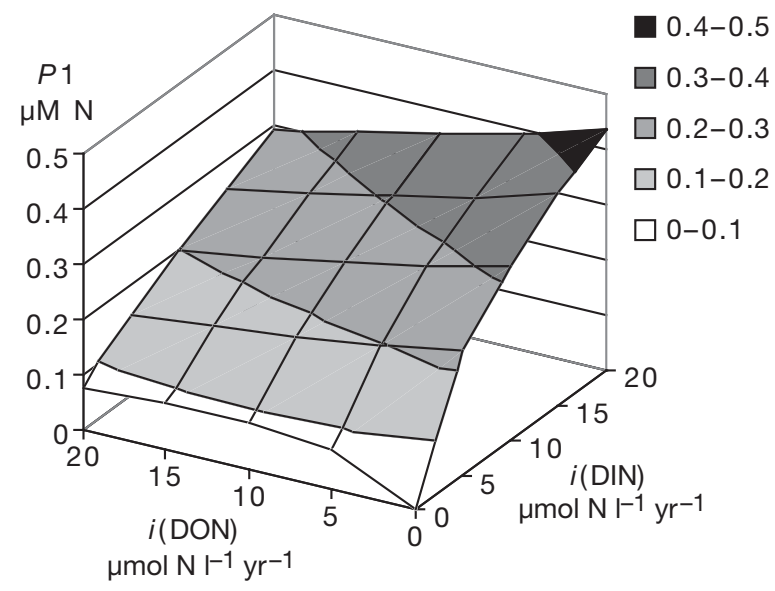

Fig. 3. Steady-state biomass of phytoplankton species $P 1$ at different input rates of DON and DIN. Simulations were done for all combinations of $i_{\mathrm{DIN}}$ and $i_{\mathrm{DON}}(0,5,10,15$ and $20 \mu \mathrm{mol}$ $\mathrm{N}^{-1} \mathrm{yr}^{-1}$ ). All steady-state outcomes are connected omitted from the model (data not shown). Bacterial biomass was positively correlated with DIN input owing to increased DON recycling by phytoplankton. The biomass of HNAN and CIL increased with DIN input (Figs. 6, 7 \& 8) as a result of higher phytoplankton biomass and production.

The extra supply of DON to the community had a pronounced positive effect on the bacterial biomass in steady state (Fig. 6). On the contrary, the correlation of $P 1$ abundance with DON input was less positive than that with DIN input and even became negative when DIN input differed from zero (Fig. 3). The increased $B$ concentration at higher DON inputs resulted in increased HNAN and CIL concentrations. This enhanced the grazing pressure on the phytoplankton so that, in the end, the extra input of nutrients only resulted in an increase in $P 3$ biomass because of its better resistance

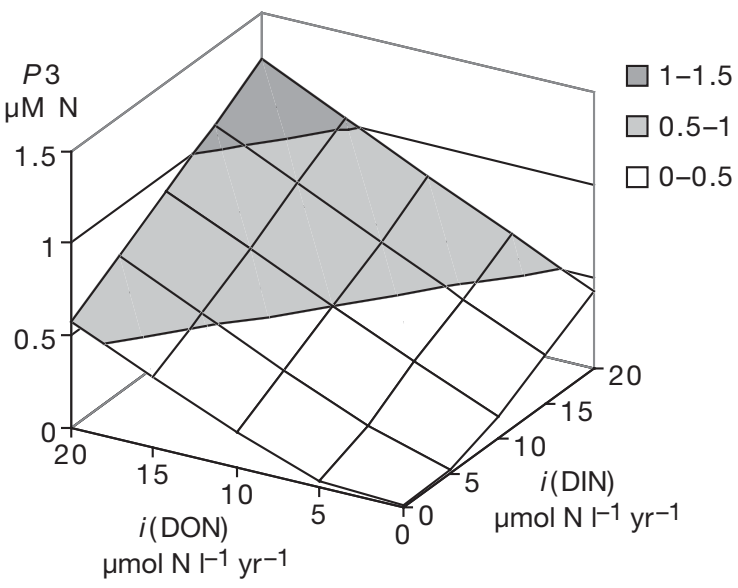

Fig. 4. Steady-state biomass of phytoplankton species $P 3$ at different input rates of DON and DIN

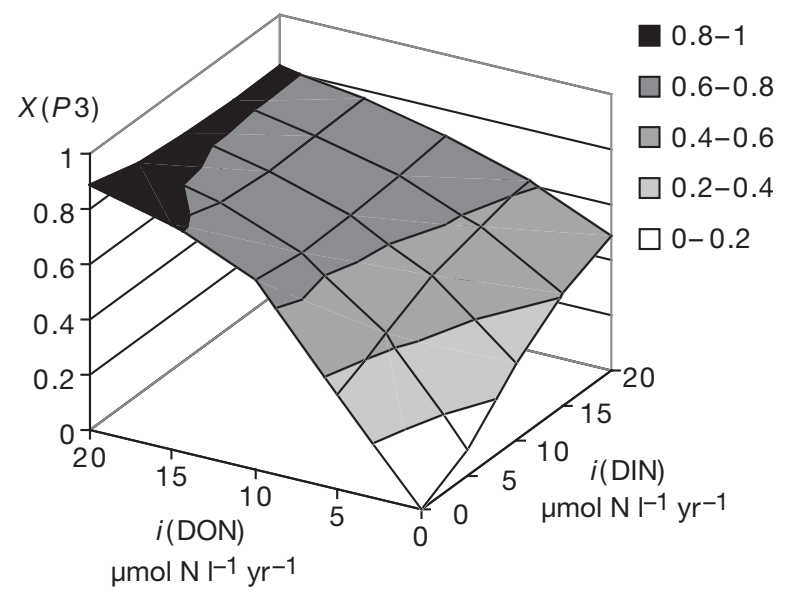

Fig. 5. Poorly edible phytoplankton species $-X(P 3)=P 3 /(P 1$ $+P 2+P 3)$ - as a proportion of total phytoplankton biomass during steady state at different input rates of DON and DIN 


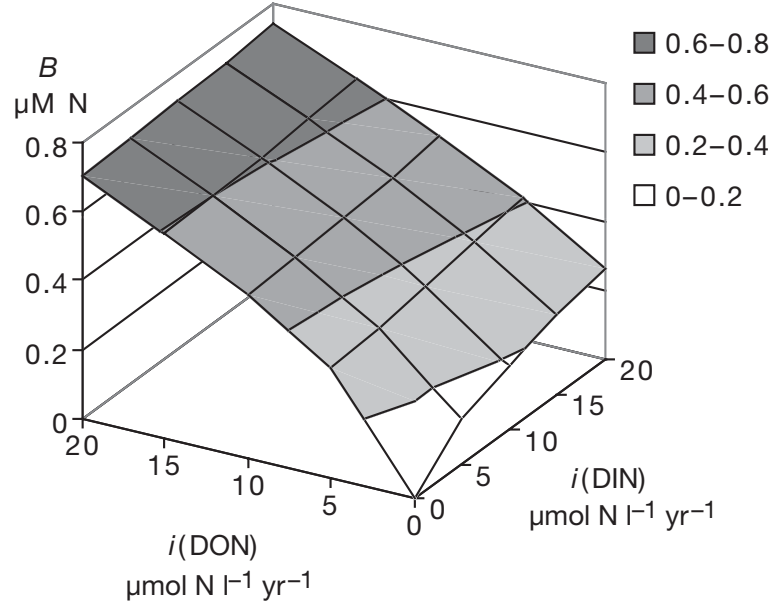

Fig. 6. Steady-state bacterial biomass $(B)$ at different input rates of DON and DIN

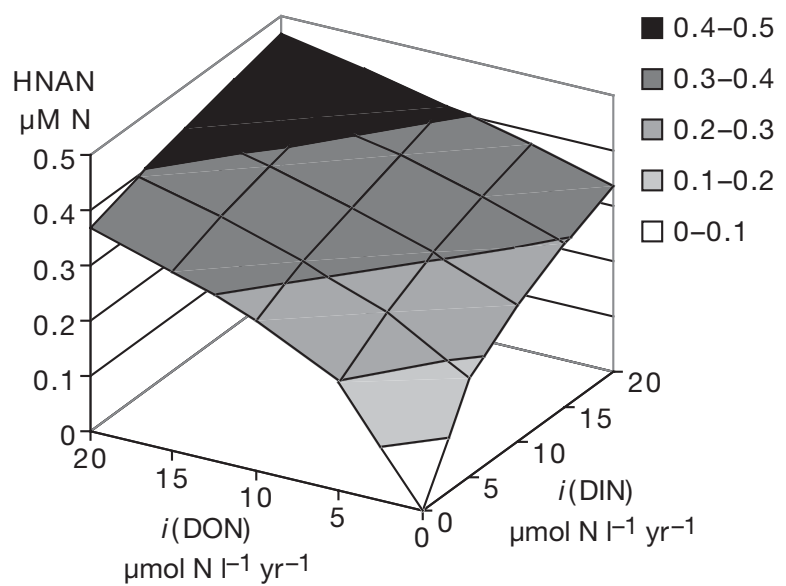

Fig. 7. Steady-state heterotrophic nanoflagellate biomass (HNAN) at different input rates of DON and DIN

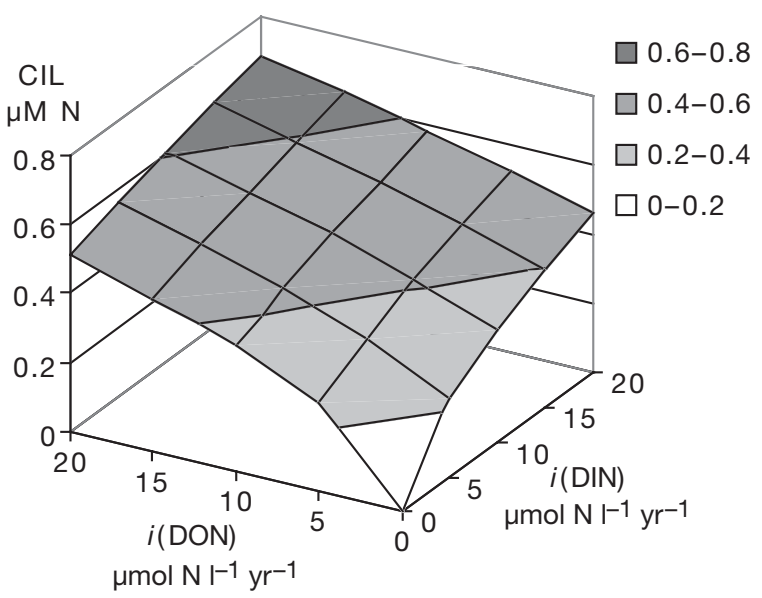

Fig. 8. Steady-state ciliate biomass (CIL) at different input rates of DON and DIN against grazing. Because $P 1$ was negatively correlated with DON input, while $P 3$ was positively correlated, the relative abundance of the poorly edible $P 3$ showed a higher correlation with DON than with DIN supply rates (Fig. 5). This may indicate that the increase in $P 3$ with increasing DON supply rates could not be explained by extra nutrient input of DON into the system alone.

\section{Short-term effects (0 to $30 \mathrm{~d})$}

The opportunistic algal species $P 2$ was usually only dominant during the first $5 \mathrm{~d}$ of simulation, depending on the start conditions. The maximum biomass of $P 2$ during that period was correlated with DIN input rate, but was also highly dependent on the start conditions. After the first 5 to $10 \mathrm{~d}, P 2$ was replaced by $P 1$ or $P 3$ depending on input rates and start conditions. This reflects the typical opportunistic character of $P 2$ : it is only able to achieve a high net growth rate when nutrient concentrations are high and grazing pressure is still low (Fig. 9).

The effect of increased DON loading on the short term was most pronounced under conditions of low DIN loading. At a DIN loading of $5 \mu \mathrm{mol} \mathrm{N}^{-1} \mathrm{yr}^{-1}$, DON input enhanced the bacterial growth rate, leading to more recycling of DON than of DIN, and subsequently to higher biomasses of $P 2$ within the first 5 to $10 \mathrm{~d}$ of the simulation. In the long term, $P 2$ was again always replaced by $P 1$ and/or $P 3$.

\section{Sensitivity analysis}

At low nutrient input rates (DIN input $5 \mu \mathrm{mol} \mathrm{N} \mathrm{l^{-1 }}$

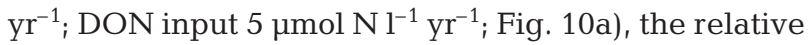
abundance of $P 3(X[P 3])$ during steady state was negatively affected by $g_{\text {max, CIL }}(\alpha=-0.26)$, leading to a $26 \%$ decrease in $X(P 3)$ resultant from a $1 \%$ increase in $g_{\text {max,CIL }}$. The same effect (but to a lesser extent) was evident with regard to $e_{\mathrm{HNAN}, \mathrm{CIL}}, k_{P 1, \mathrm{HNAN}}, \mu_{\text {max }, P 1}$ and $k_{\mathrm{DIN}, P 3}(\alpha \approx-0.1) . X(P 3)$ was clearly positively affected by the parameters $g_{\text {max,HNAN }}, K_{\mathrm{DIN}, P 1}, K_{\mathrm{HNAN}, \mathrm{CIL}}, K_{P 3, \mathrm{CIL}}$ $\mu_{\text {max }, P 3}$ and $r_{\text {CIL }}(\alpha \approx 0.1)$.

Under conditions of considerably higher nutrient input rates and equal contributions of organic and inorganic

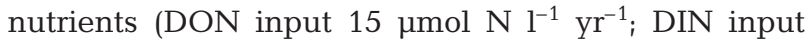
$15 \mu \mathrm{mol} \mathrm{N}{ }^{-1} \mathrm{yr}^{-1}$ ), the pattern of the sensitivity analyses was very similar to the analyses at low input rates. The steady-state biomass of $P 3$ was by far mostly dependent on $g_{\text {max,CIL }}(\alpha=-0.04)$. (Fig. 10b). In general, the relative sensitivity of $X(P 3)$ to changes in parameters was relatively low at high nutrient input rates because the steadystate biomass of $P 3$ was higher than at low input rates. 


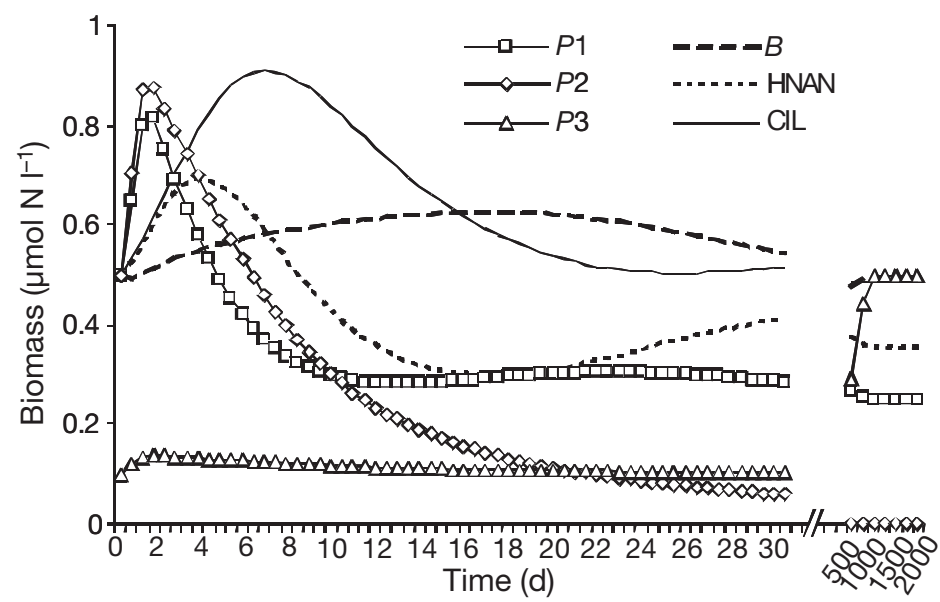

Fig. 9. Time course of model at $i_{\mathrm{DIN}}=10 \mu \mathrm{mol} \mathrm{N} \mathrm{l}^{-1} \mathrm{yr}^{-1}$,

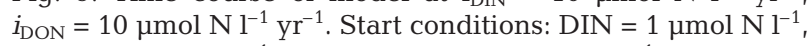
DON $=0 \mu \mathrm{mol} \mathrm{N} \mathrm{l}{ }^{-1}$; initial biomass $=0.5 \mu \mathrm{mol} \mathrm{l}^{-1}$ (except $P 3$, $=0.1 \mu \mathrm{mol} \mathrm{l^{-1 }}$ )

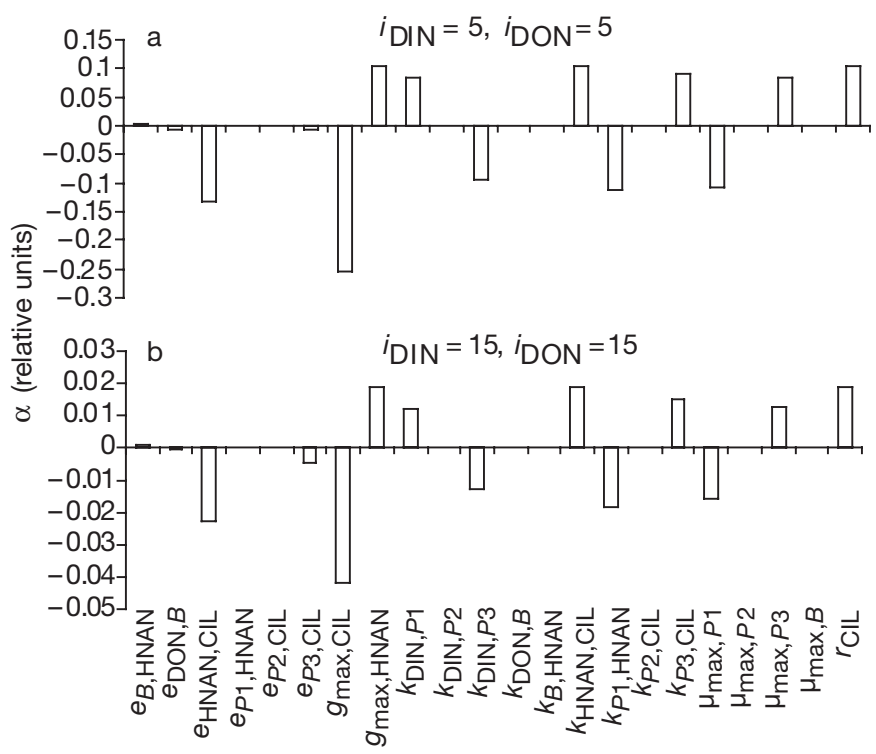

Fig. 10. Sensitivity of steady-state $P 3$ biomass derived from a $10 \%$ variation in parameter values at 2 different nutrient input rates: (a) $i_{\mathrm{DIN}}=5 \mu \mathrm{mol} \mathrm{N}{ }^{-1} \mathrm{yr}^{-1}, i_{\mathrm{DON}}=5 \mu \mathrm{mol} \mathrm{N} \mathrm{l}^{-1} \mathrm{yr}^{-1}$;

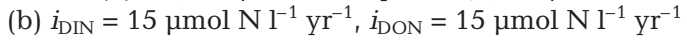

\section{DISCUSSION}

\section{Model implications}

The model results showed that the ratio of poorly edible species to other phytoplankton could increase to a greater extent as a result of DOM-bound nitrogen than when only inorganic nitrogen was supplied. These findings could provide an additional explana- tion for the formation of harmful of nuisance phytoplankton blooms in coastal areas. Some coastal areas receive considerable part of the nutrients in organic form. The Baltic Sea is an example of such an area, with frequent algal blooms that are sometimes comprised of toxic species. Growth of dinoflagellates capable of bloom formation has shown to be under weak top-down control in this area (Granéli 1993). Moreover, the addition of humic material resulted in a higher biomass of ciliates, probably owing to enhanced bacterial production (Carlsson et al. 1995). In another coastal community, it has been shown that the addition of degradable DON from atmospheric deposition leads to a phytoplankton community dominated by large diatoms and dinoflagellates (which are often poorly edible for microzooplankton) after $16 \mathrm{~d}$ of incubation. Addition of ammonium to the same natural community led to microflagellate dominance (Seitzinger \& Sanders 1999). Possibly, a stronger top-down control after DON addition had prevented the microflagellates from using all the available nitrogen, which was then available to the dinoflagellates and large diatoms. In contrast with this hypothesis, ciliate biomass reached a maximum in the ammonium-enriched experiment. This does not necessarily falsify our hypothesis of DON stimulation of heterotrophs, because during transient situations in our model simulations, zooplankton biomass was also not always positively correlated with DON and DIN supply ratio.

\section{Consequences of model results for short-term experiments}

The model results showed that the long-term effects of enhanced DIN and DON input into a pelagic microbial food web can be very different from effects obtained in shorter time intervals (1 to $2 \mathrm{wk}$ ). For practical reasons, most experimental work is only carried out within relatively short time intervals, typically 1 to $2 \mathrm{wk}$. Our results suggest that the biomass development of poorly edible, relatively slowly growing phytoplankton species might easily remain unnoticed in mesocosm experiments initiated with a natural community. We may therefore conclude that short-term phytoplankton development in general is more dependent on the initial conditions and the growth kinetics of the different species, while longterm effects are more dependent on resistance against grazing. Circumstances that can lead to a bloom of inedible phytoplankton during a season might, depending on the initial conditions, yield almost only opportunist-like species ( $P 2$ in our study) in the time scale in which mesocosm experiments are usually conducted. 


\section{Model assumptions}

Nitrogen is assumed to limit the biomass in our food web model. As a consequence, only the nitrogen budgets of the different compartments were modelled. However, nitrogen limitation at the primary producer level does not necessarily mean nitrogen limitation at all levels. Because consumers respire a large part of the ingested carbon, they will more often be carbonthan nitrogen-limited. The model accounts for this process by defining an efficiency of grazer nitrogen efficiency that is lower than $100 \%$. The portion of nitrogen that cannot efficiently be used is excreted by the grazer, and is recycled as an organic nitrogen compound in the current model, meaning that it will only be taken up by the bacterial population. Model runs where nitrogen was recycled in the form of DIN resulted in slightly elevated total phytoplankton biomass, but did not change the results in a qualitative way (results not shown).

Because one of the basic assumption is that nitrogen is the limiting factor for phytoplankton growth, it remains to be seen what the effect of DOM would be when other factors (light, other nutrients) control phytoplankton growth. In that case, the nitrogen provided by DON could be of less importance. Instead, bacterial stimulation by the externally supplied DOM could become relatively more important. Because the increase in bacterial biomass in the model resulted in an increase in grazer biomass, and subsequent higher grazing pressure on the phytoplankton community, there could still be a selection towards poorly edible phytoplankton even if a factor other than nitrogen is limiting primary production.

There was no differentiation between forms of DIN in the model. The DIN quality is likely to influence phytoplankton species composition and perhaps food web structure (Stolte et al. 1994). A possible extension of the current modelling effort could be that ammonium and nitrate are modelled separately. Although models are available for ammonium-nitrate interactions of uptake and phytoplankton growth (Stolte \& Riegman 1996, Flynn et al. 1997), such an extension would substantially increase the complexity of the current model and model results might be harder to relate to parameter values.

In our modelling study, only 1 type of HNAN and CIL was modelled. In natural communities, succession of specialized grazers during a season will both qualitatively and quantitatively influence the development of phytoplankton communities. Grazers may select for food size (Monger \& Landry 1991, 1992) or chemical signals (Christaki 1999). Some protozoan grazers can adapt to a certain food species, resulting in a variable preference for that species depending on its abundance
(Jürgens \& DeMott 1995). Furthermore, phytoplankton can become less edible in the presence of a suitable grazer. For example, colony formation in the green algae Scenedesmus acutus might effectively reduce grazing losses (Lurling \& Van Donk 1999). However, in another study, colony formation by the haptophyte Phaeocystis globosa resulted in lower growth rates at low nutrient concentrations than did single cell populations (Ploug et al. 1999). Implicitly, the model could account for grazing defence responses, assuming that 1 phytoplankton species could occupy 2 different niches, but this possibility was not further explored.

The DIN and DON loads tested with the current

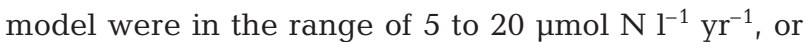

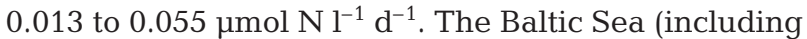
Bothnian Sea, Bothnian Bay and Baltic Proper) receives approximately $1.1 \times 10^{6}$ tons of total nitrogen per year (about half of it consisting of DON) from external input. Assuming that this nitrogen is mixed into the top $10 \mathrm{~m}$ of the water column, which has a volume of $3770 \mathrm{~km}^{3}$ (Wulff \& Stigebrandt 1989), the average volumetric input would be approximately $21 \mu \mathrm{mol} \mathrm{N} \mathrm{l}^{-1}$ $\mathrm{yr}^{-1}$, which is within the range of the DIN and DON loads that we tested. An increased mixing depth would proportionally decrease this average value. Likely, volumetric input of allochthonous DIN or DON may vary spatially and temporally by orders of magnitude, but the values used in the present study prove realistic in a coastal sea that receives high loads of DOM.

\section{Sensitivity of model results to variation in parameters}

The fact that the maximum grazing rate of CIL was by far the most important factor determining the steady-state biomass concentration of $P 3$, especially at high DIN and DON input rates, suggests that ciliates play a key role in this system. The stronger correlation of the contribution of $P 3$ to the phytoplankton community with DON than with DIN can therefore be explained as a direct positive effect of DON on the grazer community.

Additional runs showed that growth kinetics of $P 3$ did have an effect on the time scale that is required for $P 3$ to become a dominant phytoplankton species (data not shown).

\section{Effects of imported DOM in natural systems}

Areas in which DOM could play an important role are semi-enclosed seas with a high and DOM-rich freshwater input. The Baltic Sea is a large estuary receiving large amounts of DOM via rivers from the surrounding forested lands. In some regions of the 
Baltic Sea, the yearly input of imported DOM can be equal to or higher than the net primary production of the phytoplankton (Wulff \& Stigebrandt 1989, Stigebrandt 1991). Although a large proportion of this DOM is in the form of humic material, at least part of this material is directly or indirectly (via photochemical mediation) available for growth by bacteria in freshwater (Tranvik 1988) and coastal plankton communities (Carlsson et al. 1993, Zweifel et al. 1995). Based on sea surface oxygen flux calculations, large parts of the Baltic Sea, i.e. the Bothnian Sea and Bothnian Bay, are net heterotrophic communities on a yearly basis, confirming that DOM is utilized. It was concluded that the 'importance of allochthonous organic substances as carbon and energy sources for animals and bacteria should almost equal that of net production of organic matter by photosynthesis in the photic layer' (Stigebrandt 1991). Although it is recognized that carbon originating from riverine DOM can be transported up to higher trophic levels (Rolff \& Elmgren 2000), the impact of the DOM-based bacterial production on the microbial food web is poorly known.

The Baltic Sea is also an area where potentially harmful dinoflagellate, prymnesiophyte and cyanobacteria blooms that result in strong water discoloration are regularly re-occurring phenomena (e.g. Kononen et al. 1993, Leppänen et al. 1995). From sediment records, it is known that blooms of potentially toxic cyanobacteria have occurred in the Baltic Sea ecosystem since its formation approximately $7000 \mathrm{yr}$ ago (Bianchi et al. 2000), but they have increased in frequency and magnitude in the past decades probably owing to anthropogenic discharge of nutrients (Finni et al. 2001, Poutanen \& Nikkilä 2001). The availability of nutrients is a prerequisite for algal blooms, but only poorly edible species will be able to reach biomass densities that result in water discolorations. The naturally high inputs of DOM into the Baltic Sea might, through the food web effects described in this study, contribute to the occurrence of harmful algal blooms in this region.

Acknowledgements. This research was undertaken in the framework of the European Commission's (EC) EUROHAB cluster (EURopean initiative on Harmful Algal Blooms). We acknowledge support from the EC's Marine Science and Technology program under contract MAS3-CT97-0149 (DOMTOX) and EVK3-CT-1999-00015 (BIOHAB) and from the EC funded 6th framework project no. 003933 'THRESHOLDS'. Niklas Holmgren is acknowledged for model simulation discussions.

\section{LITERATURE CITED}

Andersen T (1997) Pelagic nutrient cycles: herbivores as sources and sinks, Vol 129. Springer Verlag, Berlin

Antia NJ, Harrison PJ, Oliveira L (1991) The role of dissolved organic nitrogen in phytoplankton nutrition, cell biology, and ecology. Phycologia 30:1-89

Berg GM, Glibert PM, Lomas MW, Burford MA (1997) Organic nitrogen uptake and growth by the chrysophyte Aureococcus anophagefferens during a brown tide event. Mar Biol 129:377-387

Bianchi TS, Engelhaupt E, Westman P, Andrén T, Rolff C, Elmgren R (2000) Cyanobacterial blooms in the Baltic Sea: Natural or human-induced? Limnol Oceanogr 45:716-726

Burmaster DE (1979) The continuous culture of phytoplankton: mathematical equivalence among three steady state models. Am Nat 113:123-134

Carlsson P, Segatto AZ, Granéli E (1993) Nitrogen bound to humic matter of terrestrial origin - a nitrogen pool for coastal phytoplankton? Mar Ecol Prog Ser 97:105-116

Carlsson P, Granéli E, Tester P, Boni L (1995) Influences of riverine humic substances on bacteria, protozoa, phytoplankton, and copepods in a coastal plankton community. Mar Ecol Progr Ser 127:213-221

Christaki U, Dolan JR, Pelegri S, Rassoulzadegan F (1998) Consumption of picoplankton-size particles by marine ciliates: effects of physiological state of the ciliate and particle quality. Limnol Oceanogr 43:458-464

Christaki U, Jacquet S, Dolan JR, Vaulot S, Rassoulzadegan F (1999) Growth and grazing on Prochlorococcus and Synechococcus by two marine ciliates. Limnol Oceanogr 44: $52-61$

Fasham MJR, Boyd PW, Savidge G (1999) Modeling the relative contributions of autotrophs and heterotrophs to carbon flow at a Lagrangian JGOFS station in the Northeast Atlantic: the importance of DOC. Limnol Oceanogr 44:80-94

Finni T, Kononen K, Olsonen R, Wallström K (2001) The history of cyanobacterial blooms in the Baltic Sea. Ambio 30:172-178

Flynn KJ, Fasham MJR, Hipkin CR (1997) Modelling the interactions between ammonium and nitrate uptake in marine phytoplankton. Phil Trans R Soc Lond B 29: 1625-1645

Granéli E, Olsson P, Carlsso P, Granéli W, Nylander C (1993) Weak 'top-down' control of dinoflagellate growth in the coastal Skagerrak. J Plankton Res 15:213-237

Jürgens K, DeMott WR (1995) Behavioral flexibility in prey selection by bacterivorous nanoflagellates. Limnol Oceanogr 40:1503-1507

Kononen K, Sivonen K, Lehtimaki J (1993) Toxicity of phytoplankton blooms in the Gulf of Finland and Gulf of Bothnia, Baltic Sea. In: Smayda TJ, Shimizu Y (ed) Toxic phytoplankton blooms in the sea. Elsevier, Amsterdam, p 269-274

Legrand C, Carlsson P (1998) Uptake of high molecular weight dextran by the dinoflagellate Alexandrium catenella. Aquat Microb Ecol 16:81-86

Leppänen JM, Rantajärvi E, Hällfors S, Kruskopf M, Laine V (1995) Unattended monitoring of potentially toxic phytoplankton species in the Baltic Sea in 1993. J Plankton Res 17:891-902

Lurling M, Van Donk E (1999) Grazer-induced colony formation in Scenedesmus acutus (Chlorophyceae): ecomorph expression at different temperatures. J Phycol 35: $1120-1126$

Monger BC, Landry MR (1991) Prey-size dependency of grazing by free-living marine flagellates. Mar Ecol Prog Ser 74:239-248

Monger BC, Landry MR (1992) Size-selective grazing by heterotrophic nanoflagellates: an analysis using live-stained bacteria. Arch Hydrobiol Beih 37:173-185 
Ploug H, Stolte W, Jørgensen BB (1999) Diffusive boundary layers of the colony-forming plankton alga Phaeocystis sp.: implications for nutrient uptake and cellular growth. Limnol Oceanogr 44:1959-1967

Poutanen EL, Nikkilä K (2001) Carotenoid pigments as tracers of cyanobacterial blooms in recent an post-glacial sediments of the Baltic Sea. Ambio 30:184-189

Rhee GY (1973) A continuous culture study of phosphate uptake, growth rate and polyphosphate in Scenedesmus sp. J Phycol 9:495-506

Riegman R, Kuipers BR (1994) Resource competition and selective grazing of plankton in a multispecies pelagic food web model. PSZN I: Mar Ecol 15:153-164

Rolff C, Elmgren R (2000) Use of riverine organic matter in plankton food webs of the Baltic Sea. Mar Ecol Prog Ser 197:81-101

Seitzinger SP, Sanders RW (1999) Atmospheric inputs of dissolved organic nitrogen stimulate estuarine bacteria and phytoplankton. Limnol Oceanogr 44:721-730

Stepanauskas R, Laudon H, Joergensen NOG (2000) High DON bioavailability in boreal streams during a spring flood. Limnol Oceanogr 45:1298-1307

Stigebrandt A (1991) Computations of oxygen fluxes through the sea surface and the net production of organic matter with application to the Baltic and adjacent seas. Limnol Oceanogr 36:444-454

Stolte W, Riegman R (1995) The effect of phytoplankton cell size on transient state nitrate and ammonium uptake kinetics. Microbiology 141:1221-1229

Editorial responsibility: Frede Thingstad, Bergen, Norway
Stolte W, Riegman R (1996) A model approach for size selective competition of phytoplankton for fluctuating nitrate and ammonium. J Phycol 32:732-740

Stolte W, McCollin T, Noordeloos AAM, Riegman R (1994) Effect of nitrogen source on the size distribution within marine phytoplankton populations. J Exp Mar Biol Ecol 184:83-97

Thingstad TF, Sakshaug E (1990) Control of phytoplankton growth in nutrient recycling ecosystems. Theory and terminology. Mar Ecol Prog Ser 63:261-272

Tranvik LJ (1988) Availability of dissolved organic carbon for planktonic bacteria in oligotrophic lakes of differing humic content. Microb Ecol 16:311-322

Turner JT (2006) Harmful algae interactions with marine planktonic grazers. In: Granéli E, Turner JT (eds) Ecology of harmful algae. Ecological studies, Vol 198. SpringerVerlag Berlin, p 259-270

Turner JT, Tester PA (1997) Toxic marine phytoplankton, zooplankton grazers and pelagic food webs. Limnol Oceanogr 42:1203-1214

Wulff F, Stigebrandt A (1989) A time-dependent budget model for nutrients in the Baltic Sea. Global Biogeochem Cycles 3:63-78

Zingone A, Enevoldsen HO (2000) The diversity of harmful algal blooms: a challenge for science and management. Ocean Coast Manag 43:725-748

Zweifel UL, Wikner J, Hagström Å, Lundberg E, Norrman B (1995) Dynamics of dissolved organic carbon in a coastal ecosystem. Limnol Oceanogr 40:299-305

Submitted: January 27, 2003; Accepted: January 17, 2007 Proofs received from author(s): March 6, 2007 